\title{
В.А. Печерский
}

\section{ПРОКУРОРСКИЕ ОРГАНЫ ХАКАССКОЙ АВТОНОМНОЙ ОБЛАСТИ В ПОСТСТАЛИНСКИЙ ПЕРИОД (1953-1960 гг.)}

\begin{abstract}
Рассматриваются вопросы, связанные с деятельностью прокурорских органов Хакасии в период между смертью И.В. Сталина и прекращением действия Уголовного кодекса РСФСР 1926 г. Сотрудникам прокуратур приходилось работать в новых политических условиях, основываясь на старом законодательстве. Прокурорские органы Хакасии в исследуемый период испытывали серьезные трудности с кадровым составом, при растущей численности населения области число прокурорских работников оставалось неизменным, поэтому возрастала нагрузка на имевшихся сотрудников.

Ключевые слова: Хакасская автономная область; прокурорские органы; постсталинский период; правопорядок.
\end{abstract}

После смерти И.В. Сталина 5 марта 1953 г. в стране начались реформы, в ходе которых прокурорским органам отводилась заметная роль.

Деятельности органов прокуратуры в период хрущёвской «оттепели» уделено внимание в учебном пособии под редакцией А.Г. Звягинцева [1]. Также перу А.Г. Звягинцева принадлежит книга о генеральном прокуроре СССР исследуемого периода Р.А. Руденко [2]. Жизнеописанию высокопоставленных прокурорских работников посвящен труд А.Г. Звягинцева и Ю.Г. Орлова [3]. Непосредственно история территориальных органов прокуратуры исследуется в диссертации М.В. Кирячева [4]. Функционирование прокурорских органов в Тувинской автономной области показано в работе 3.Ю. Доржу и И.Д. Шмидта [5].

В данной статье речь пойдет о деятельности, структуре и кадровом составе прокурорских органов Хакасской автономной области с 1953 г. - даты смерти И.В. Сталина, до 1960 г., последнего года действия Уголовного кодекса РСФСР 1926 г.

По мнению М.В. Кирячева, «сталинский период оставил тяжелое наследие системе прокурорского надзора СССР. Имея статус высшего надзорного органа, советская прокуратура вплоть до 1953 г. не имела возможности полностью выполнять возлагавшихся на нее задач по охране законности» [4. С. 12].

При всей спорности этого утверждения было ясно, что прокурорские органы нуждались в изменениях. Проведением таких реорганизаций занялся Р.А. Руденко, назначенный в июне 1953 г. Генеральным прокурором СССР. В своем приказе от 19 июня 1954 г. Роман Андреевич потребовал от прокурорских работников правильно и своевременно разрешать первичные материалы и сообщения о совершавшихся преступлениях [2. С. 163]. Приказ Р.А. Руденко от 4 августа 1955 г. усилил прокурорский надзор за соблюдением законности при задержании, аресте и привлечении к уголовной ответственности граждан. А приказ Генерального прокурора от 1 августа 1956 г. передавал надзор за следственными делами о государственных преступлениях, совершавшихся гражданскими лицами, от военных прокуратур прокуратурам областей, краёв, союзных и автономных республик [3. C. 83].

24 мая 1955 г. Указом Президиума Верховного Совета СССР было утверждено Положение о прокурорском надзоре в СССР. Статья 1 этого нормативного правового акта подтверждала положение ст. 113
Конституции СССР, возлагавшей надзор за точным исполнением законов всеми министерствами и подведомственными им учреждениями, должностными лицами и гражданами СССР на Генерального прокурора СССР. Высший надзор имел целью укрепление в стране «социалистической законности» [7. С. 141].

Таким образом, взятый руководством страны курс на восстановление «социалистической законности» предусматривал в числе прочего увеличение роли прокуратуры в процессе поддержания законности. Это выразилось в активности прокурорских органов, возросшей в исследуемый период.

Так, по общенадзорной работе в 1953 г. прокурорскими органами Хакасской автономной области было проведено 754 проверки исполнения различных законов, в 1954 г. было проведено уже 867 таких проверок. По их результатам прокурорские работники в 1953 г. вынесли 203 протеста, в 1954 г. - 429, и внесли представлений 209 и 258 соответственно. По представлениям прокуроров в 1953 г. было привлечено к дисциплинарной ответственности 222 человека, в 1954 г. - 377. Таким образом, увеличилось не только количество проверок нарушения законов, но и эффективность таковых, в 1953 г. 79,6\% проверок принесли результат, в 1954 г. - 94\% [6. Л. 9].

Одним из наиболее распространенных видов правонарушений в исследуемый период было нарушение Устава сельскохозяйственной артели в колхозах. Жесткие рамки, в которые были поставлены коллективные хозяйства, заставляли их руководителей и членов нарушать законодательство. Масштаб таких отклонений от закона вынудил Совет Министров СССР и ЦК ВКП(б) принять 19 сентября 1946 г. Постановление «О мерах по ликвидации нарушений Устава сельскохозяйственной артели в колхозах» [8. С. 173]. В Постановлении были отмечены «неправильное расходование трудодней, расхищение общественных земель колхозов, растаскивание колхозной собственности» [Там же]. Положения данного законодательного акта оставались актуальными до середины 1950-х гг., и сотрудники прокурорских органов области периодически проводили проверку их соблюдения. В 1953 г. в Хакасии были произведены 142 проверки в колхозах, в ходе 112 были выявлены нарушения, в 1954 г. таких проверок было уже 247, в процессе 223 обнаружились нарушения закона. В 1953 г. прокуратуры принесли 69 протестов и внесли 74 представления по делам о нарушении Уставов 
сельхозартелей, в 1954 г. было 86 протестов и 67 представлений. По эти же делам в 1953 г. было привлечено к ответственности 89 человек, в 1954 г. 136 [6. Л. 11].

Небрежное отношение к колхозной собственности с 1930-х гг. рассматривалось как уголовное преступление. Такое же отношение сохранялось и в 1950-е гг., поэтому проверки соблюдения устава сельхозартели нередко заканчивались возбуждением уголовных дел. Колхозы являлись основой сельскохозяйственного производства в стране, и сохранение их производственной базы было одним из приоритетных направлений во внутренней политике Советского Союза.

Для проверки исполнения Указа Президиума Верховного Совета СССР от 4 июня 1947 г. «Об уголовной ответственности за хищения государственного и общественного имущества» прокуратура ХАО в 1953 г. провела 167 проверок, а в 1954 г. - 172. Из них проверок, в ходе которых были выявлены нарушения закона в 1953 г., было 141, в 1954 г. - 162. В 1953 г. по названному Указу областной прокуратурой было принесено 8 протестов, в 1954 г. - 162, было внесено представлений 22 и 49 соответственно [Там же. Л. 16]. Прокурорские работники проявляли активность в духе нового времени в защите положений сталинского законодательного акта. Данный Указ действовал до 19 декабря 1960 г. и утратил силу в связи с вступлением в действие нового Уголовного кодекса РСФСР. До этого же времени прокурорским органам приходилось в точности исполнять и следить за тем, чтобы и другие исполняли репрессивные акты ушедшего времени.

Защищая права трудящихся, хакасские органы прокуратуры в 1953 г. произвели 137 проверок исполнения законов о труде, трудовой дисциплине и технике безопасности, в ходе 129 проверок были выявлены различные нарушения, в 1954 г. была 171 проверка, 168 выявили нарушения. Прокурорские работники в 1953 г. принесли 67 протестов и внесли 20 представлений, в 1954 г. - соответственно 193 и 53. За нарушение трудового законодательства в 1953 г. было привлечено к ответственности 4 человека, в 1954 г. 22. Наиболее распространенным видом нарушения законов о труде было несоблюдение режима рабочего дня. Оно было выявлено в 1953-1954 гг. в таких организациях, как «Нефтеразведка», «Хакасзолото», «Хакасуголь» и «Хакаслес» [Там же. Л. 18]. Перечисленные тресты составляли основу экономики области, им было сложно выполнять государственные задания без нарушения режима рабочего дня. Такие отклонения от закона пресекались прокурорскими работниками, и руководителям производственных организаций приходилось искать законные пути для выполнения планов.

Нарушения устава сельхозартелей продолжали оставаться одним из наиболее распространенных видов правонарушений. В 1956 г. наибольшее количество таких деяний было зарегистрировано в УстьАбаканском, Аскизском и Алтайском районах. По представлению областной прокуратуры эти вопросы были рассмотрены на заседании бюро обкома, которое обязало райкомы и райисполкомы исправить до- пущенные ошибки. Главными нарушителями законов о труде в 1956 г. были МТС и совхозы. Там имели место незаконные удержания из заработной платы, нарушения законов о труде женщин и подростков, несоблюдение техники безопасности. У прокурорских органов имелись претензии и к районным финансовым отделам, которые нарушали закон при обложении граждан налогами и обязательными поставками сельхозпродуктов. Всего в 1956 г. органы прокуратуры опротестовали 445 незаконных правовых актов и внесли 195 представлений [9. Л. 30-32].

Меры, предпринятые прокурорскими органами в 1953-1954 гг. в отношении промышленных трестов дали определенный результат, однако нарушения трудового законодательства росли в других организациях, и прокурорским работникам пришлось перенести свое внимание туда. Устав сельскохозяйственной артели по-прежнему оставался сдерживающим фактором в развитии колхозов, о чем свидетельствовало большое количество его нарушений. Незаконное обложение граждан налогами являло собой пример некомпетентности сотрудников финансовых отделов.

Одной из самых важных функций прокурорских органов была защита прав и законных интересов граждан. В 1954 г. в органы прокуратуры Хакасии поступило 7476 жалоб, из них в городские и районные прокуратуры - 1224 , остальные - в областную прокуратуру. Это было на 365 жалоб больше, чем за 1953 г. Люди шли жаловаться в прокуратуры, прежде всего на исполнение судебных решений по делам о взыскании алиментов и по трудовым правоотношениям.

За первые 10 месяцев 1957 г. в городские и районные прокуратуры области поступило 7773 жалобы и заявления граждан, за тот же период 1958 г. - 6 607, из которых периферийные органы прокуратуры сами разрешили 75\% жалоб, 25\% направили в другие ведомства. Прокуроры удовлетворяли около 20\% полученных жалоб. За первые 10 месяцев 1958 г. прокурорам поступило 506 жалоб на решения судов, из них было удовлетворено 6\% [10. Л. 91-92]. Иной раз прокурорские органы оставались последней надеждой для граждан, которые не нашли справедливости в партийных органах, органах государственной власти, в судах.

В первые послесталинские годы актуальным был вопрос следственной работы прокурорских органов. В 1953 г. правоохранительные органы области расследовали 2132 дела, из них 51,4\% - прокуратуры. В 1954 г. было расследовано 2132 дела, из них прокуратурами - 56,1\% [6. Л. 23]. Роль прокуратуры как следственного органа возросла в 1954 г. в связи с падением всесильного главы МВД Л.П. Берии. Некогда подчиненное ему ведомство потеряло былое значение.

Растраты и хищения наносили огромный урон народному хозяйству СССР, поэтому расследованию этих преступлений в прокурорских органах уделялось особое внимание. В 1954 г. следователи прокуратур Хакасии окончили расследование 254 таких уголовных дел, из которых направили в суд 237 против 236 в 1953 г. К уголовной ответственности в 1954 г. было привлечено 355 расхитителей государственного и общественного имущества против 375 в 1953 г. Из при- 
влеченных к уголовной ответственности за расхищение государственного и общественного имущества в 1954 г. 63 человека работали в государственной торговле, 58 - в потребительской кооперации, 18 - в промысловой кооперации, 104 - в колхозах, 72 - на промышленных предприятиях, 40 - в других организациях. Расхитители в 1954 г. нанесли материальный ущерб государственным и общественным организациям области на сумму 1263074 руб., в возмещение которого было описано имущества и изъято ценностей на 491958 руб. [6. Л. 27].

Количество таких преступлений с годами росло. В 1956 г. в области было установлено 197 случаев растрат и хищений на сумму 891800 руб., в 1957 г. таких случаев было 207, а государство потеряло 1007000 руб. В 1957 г. органы прокуратуры ХАО привлекли за растраты и хищения 81 сотрудника государственной торговли и потребительской кооперации, 52 работников совхозов, 24 членов колхозов и других лиц [11. Л. 11]. Хищения социалистической собственности имели место и на промышленных предприятиях, где частыми были случаи краж горюче-смазочных материалов. В 1957 г. областная прокуратура занималась расследованием по фактам хищения таковых из Абаканской нефтебазы, Хакасской автомобильной роты, Абаканской и Черногорской автотранспортной контор [12. Л. 9].

Большинство хищений совершалось в сфере торговли, работники которой имели доступ к денежным средствам и материальным ценностям. Дефицит товаров делал этот вид преступлений чрезвычайно выгодным, поскольку позволял расхитителям значительно обогащаться, реализовывая краденое на черном рынке. Нехватка продуктов питания, бензина, машинного масла провоцировала хищения в сельском хозяйстве и промышленности.

Различные виды преступлений, с которыми приходилось бороться работникам прокуратуры, имели тенденцию и к росту, и к сокращению. Так, в 1953 г. в области было совершено 208 краж личной собственности, в 1954 г. - 140. Количество хулиганских проявлений сократилось с 411 в 1953 г. до 342 в 1954 г. Умышленных убийств в 1953 г. было 38, в 1954 г. - 42 [6. Л. 34].

Работая с населением, милиции и прокурорским органам удалось сократить число хулиганских проявлений и краж. Однако с 1953 по 1954 г. выросло количество преступлений против личности. Объяснялось это распространением употребления спиртных напитков, выходом на свободу большого количества бывших заключённых по Указу Президиума Верховного Совета СССР об амнистии от 27 марта 1953 г., общей атмосферой свободы, иногда переходящей во вседозволенность, возникшей после прекращения массовых репрессий.

Кроме борьбы с разными видами преступлений, работникам прокуратуры приходилось следить за работой милиции. В 1954 г. отделом по надзору за органами милиции областной прокуратуры было внесено 13 представлений в областное и краевое управления МВД о нарушениях служебных обязанностей сотрудниками милиции [Там же. Л. 47].

Одной из претензий к милиции со стороны прокуратуры была низкая раскрываемость преступлений, что видно из таблицы.

Раскрываемость преступлений в Хакасии [6. Л. 47]

\begin{tabular}{|c|c|c|c|c|c|c|c|c|}
\hline \multirow{2}{*}{$\begin{array}{c}\text { Вид } \\
\text { преступлений }\end{array}$} & \multicolumn{2}{|c|}{$\begin{array}{c}\text { Зарегистрировано } \\
\text { преступлений }\end{array}$} & \multicolumn{2}{|c|}{ Из них раскрыто } & \multicolumn{2}{|c|}{$\begin{array}{c}\text { Процент } \\
\text { раскрываемости }\end{array}$} & \multicolumn{2}{|c|}{$\begin{array}{c}\text { Число преданных } \\
\text { суду лиц }\end{array}$} \\
\hline & 1954 г. & 1953 г. & 1954 г. & 1953 г. & 1954 г. & 1953 г. & 1954 г. & 1953 г. \\
\hline Разбой & 35 & 59 & 24 & 46 & 68,5 & 77,9 & 53 & 71 \\
\hline Убийства & 19 & 33 & 31 & 19 & 100 & 93,9 & 22 & 42 \\
\hline Кражи & 374 & 560 & 250 & 380 & 66,8 & 67,8 & 372 & 443 \\
\hline Хулиганство & 326 & 413 & 320 & 406 & 98,1 & 98 & 445 & 534 \\
\hline
\end{tabular}

Данные областного управления милиции отличались от подлинного количества преступлений в указанный период. Это было связано с тем, что значительная часть дел расследовалась прокуратурами и эти дела не находились на учёте в милиции.

Вместе с ростом преступности падала раскрываемость преступлений. Недостаточная квалификация и неопытность сотрудников милиции не позволяли им раскрывать большее количество криминальных деяний, случавшихся в области. Расхождение данных о количестве преступлений не позволяло как милиционерам, так и прокурорским работникам составить целостную картину преступности в Хакасии, что мешало борьбе с ней, приводило к несогласованности в действиях различных ведомств.

Наметившееся в середине 1950-х гг. снижение преступности по РСФСР затронула и Хакасию. Анализируя криминальную обстановку в области в 1956 г., областной прокурор С.П. Адушкин отметил, что уровень преступности в Российской Федерации в 1956 г. по сравнению с 1946 г. снизился на треть, в области за тот же период количество лиц, преданных суду, упало на $26 \%$. При этом тенденция роста таких видов преступлений как убийства, изнасилования, нанесение тяжких телесных повреждений, злостное хулиганство, хищения социалистической и личной собственности, сохранялась. В 1956 г. число лиц, преданных суду за эти деяния, возросло по сравнению с 1955 г. на 28\%. Увеличению количества некоторых видов преступлений, по мнению областного прокурора, способствовали рост числа направляемых в Хакасию осужденных для отбытия ссылки и низкая раскрываемость преступлений. Иной раз сотрудники милиции занижали уровень преступности, не регистрируя криминальные проявления. Так, областное УМВД заявляло, что все совершенные в 1956 г. убийства были раскрыты, а по сведениям Хакасской прокуратуры, два убийства остались не раскрытыми. Проверкой, проведенной сотрудниками прокурорских органов, было установлено, что в Туимском поселковом отделении милиции к началу ноября 1956 г. оставались незарегистрированными 38 различных преступлений, в большинстве 
своем - кражи. В Усть-Абаканском районном отделении не было зарегистрировано 12 преступлений, Алтайском - 8, Черногорском городском - 9. В 1956 г. в хирургическое отделение Абаканской городской больницы поступило 37 человек с огнестрельными и ножевыми ранениями, при этом в городском отделе милиции было зарегистрировано лишь 13 эпизодов. Также имели место случаи, когда, раскрыв преступление, сотрудники милиции не затрудняли себя поиском всех виновных [9. Л. 2-5].

Большая загруженность работников отделений МВД, желание показать собственные достижения, скрыв часть преступлений, провоцировали у преступников чувство безнаказанности и в конечном счете приводили к росту криминальной активности.

Характерным примером такого равнодушного отношения милиционеров к своим обязанностям было расследование убийства молодого рабочего Анатолия Бахтина в Черногорске. 22 августа 1956 г. он был избит и ранен ножом на танцплощадке. После инцидента Анатолий жил еще 16 часов и был в сознании, однако сотрудники милиции не сочли нужным допросить молодого человека, поэтому мать погибшего 19 ноября 1956 г. обратилась с жалобой в областную прокуратуру, следователь которой установил личность убийцы [Там же. Л. 8-9].

Прокурорские органы вели следственную работу на более высоком уровне, чем милиция. В 1956 г. суды области вернули прокуратурам на дополнительное расследование $1,3 \%$ дел, что было ниже, чем в среднем по РСФСР и по Красноярскому краю, но в ряде случаев качество и полнота следствия, проводимого прокурорскими работниками, оставались неудовлетворительными. В 1956 г. прокурору Аскизского района Черкасову на доследование было возвращено 4 дела, Ширинского района Балакиреву - 3, Алтайского района Жихареву - 2. Областной прокурор был вынужден отметить, что сотрудники прокуратуры Ширинского района не только некачественно проводили расследования, но и безграмотно оформляли следственные документы. В 1957 г. работа данного органа ухудшилась, в первом квартале туда было возвращено 6 дел. Такие серьезные огрехи нельзя было объяснить только чрезмерной загруженностью прокурорских работников Ширинского района, в нем работали 2 следователя, которые в 1956 г. направили в суд 134 дела, за тот же период прокуратура Таштыпского района, в штате которой был один следователь, направила в суд 102 дела, из которых ни одно не было возвращено на доследование [Там же. Л. 11-12].

В конце 1950-х гг. в области сохранялся довольно высокий уровень преступности при достаточно низкой раскрываемости. В 1958 г. сотрудниками прокурорских и милицейских органов было раскрыто 93\% совершенных в Хакасии преступлений. При этом нераскрытыми остались 12\% грабежей, 17\% краж государственной и $11 \%$ личной собственности. Не раскрыто было одно убийство. Наименьшая раскрываемость наблюдалась в областном центре, в Абакане она составляла 88\%. По мнению С.П. Адушкина, низкая раскрываемость преступлений во вверенной ему области объяснялась «серьезными упущениями в рас- следовании конкретных дел, а прокуроры не осуществляют должного руководства и надзора за следствием, поэтому часть преступлений остается не раскрытыми, по некоторым установлены не все преступники» [12. Л. 8]. В Абакане, самом большом городе Хакасии и крупном транспортном узле на юге Сибири, раскрывать преступления было сложнее, нежели в сельской местности.

Конец 1950-х гг. был отмечен либерализацией уголовного законодательства. К преступившим закон начали применяться меры наказания, не связанные с тюремным заключением. Важное место в процессе борьбы с преступностью стало отводиться общественности [13. С. 397].

О роли общественности на XXI съезде КПСС в январе 1959 г. сказал Н.С. Хрущёв: «Наши общественные организации имеют не меньше возможностей, средств и сил для борьбы с нарушителями социалистического порядка, нежели органы милиции, суда и прокуратуры» [14. С. 104].

Несмотря на то, что после съезда органы правопорядка получили указания на более широкое применение методов убеждения и проведение предупредительных и профилактических мер, отказаться от тотальных репрессий они смогли не сразу. Поэтому Секретариат ЦК КПСС специальным Постановлением обратил внимание на то, что органы прокуратуры, суда и милиции не сделали правильных выводов из указаний руководства партии съезда: «Вместо усиления роли общественности в охране общественного порядка судебно-следственные органы допустили серьезные недостатки в практике привлечения граждан к судебной ответственности за малозначительные преступления» [15. Л. 1-3].

Инерция сталинских времен была столь велика, что даже мнение Первого секретаря ЦК КПСС, высказанное на главном партийном форуме, не явилось для правоохранителей указанием к действию. Для поворота бюрократической машины необходимо было издать не один законодательный акт и постоянно контролировать работу судебно-следственных органов, руководство которых в большинстве составляли старые кадры и поэтому с большим трудом приспосабливалось к новым условиям работы.

За первые 8 месяцев 1960 г. судебные, милицейские и прокурорские органы области передали на поруки трудовым коллективам и общественным организациям 487 человек, совершивших незначительные преступления. По данным, имевшимся у областной прокуратуры, лица, взятые на поруки, не допускали повторных правонарушений, добросовестно работали и хорошо вели себя в быту. Некоторые сотрудники судебных и правоохранительных органов буквально поняли распоряжение сверху о передаче части правонарушителей на перевоспитание и стали навязывать трудовым коллективам и общественным организациям таких нарушителей закона. Областная прокуратура предостерегала от подобной практики, предупреждала, что инициатива должна была исходить от самих коллективов, а не от следственных органов [Там же. 22-23].

Институт передачи на поруки был тем новшеством, с помощью которого Н.С. Хрущёв хотел ди- 
станцироваться от сталинской эпохи с ее жестким отношением ко всем категориям правонарушителей и завоевать симпатии в обществе. Кроме того, содержание заключенных обходилось государству слишком дорого и уменьшение их количества позволило бы сократить финансирование мест заключения.

По мнению Н.Б. Лебиной, в либерализации уголовного законодательства «не последнюю роль сыграло и целенаправленное изменение общественных представлений о преступлении как социальной аномалии» [13. С. 397]. С подачи Никиты Сергеевича преступники больше не считались окончательно потерянными для общества людьми, для них сохранялась надежда на возвращение к нормальной жизни.

Мягкое отношение к впервые преступившим закон повлияло на уровень преступности в области. За первые 8 месяцев 1960 г. прокурорские органы Хакасии возбудили на $15 \%$ меньше уголовных дел, чем за тот же период 1959 г. Снижение произошло за счет преступлений небольшой тяжести: мелких хищений, незлостного хулиганства, некоторых должностных преступлений. За то же время число умышленных убийств выросло на 35\%, тяжких телесных повреждений - в 2 раза, изнасилований - на $26 \%$, разбойных нападений - на 42, краж личной собственности граждан - на 26, хищений государственной и общественной собственности - на 7\%. Всего опасных преступлений было больше на 23\%. Наиболее значительный рост таких деяний был зафиксирован в Абакане, Черногорске и Усть-Абаканском районе [15. Л. 1].

Мониторинг криминальной ситуации в Хакасии, проведенный областной прокуратурой, показал причину этого явления. В 1954-1959 гг. в стране было несколько амнистий, за эти годы было досрочно освобождено почти 960 тыс. заключенных [16. С. 130-131]. Как отметил начальник следственного отдела областной прокуратуры Ерошин, «в конце 1959 г. и в первом полугодии 1960 г. в область прибыло большое количество лиц, освобожденных из мест заключения Комиссиями Верховного Совета Союза ССР. Значительная часть их не пожелала честно трудиться, вновь встала на преступный путь. За этой категорией граждан органами милиции следовало установить наблюдение, принять исчерпывающие меры к предупреждению новых преступлений» [15. Л. 7]. Недовольство работой органов милиции представитель областной прокуратуры выразил риторическим вопросом: «Разве можно признать нормальным, что в течение первого полугодия 1960 г. 22\% досрочно освобожденных вновь совершили преступления и привлечены к уголовной ответственности?» [Там же].

Многие отбывшие наказание после освобождения вновь начинали вести преступный образ жизни, и прокурорский работник был возмущен тем, что значительное количество тех, кому государство оказало доверие, досрочно освободив из мест заключения, снова преступили закон. Также его претензии были адресованы милиции, которая не контролировала должным образом поведение потенциально опасных лиц.

Особое место в деятельности прокурорских органов занимала работа по соблюдению законности в части арестов и обоснованности привлечения к судебной ответственности. Выполняя эти обязанности, прокуроры оказывались между двух огней: с одной стороны, они должны были защищать граждан от необоснованных заключений под стражу, с другой помогать милиции и сами вести борьбу с преступностью. До 1954 г. прокурорские работники, стараясь перестраховаться, поэтому, как правило, подписывали как можно большее число санкций на арест. Позднее ситуация стала меняться.

Всего за 1954 г. городские и районные прокуратуры Хакасии выдали санкции на арест в отношении 839 человек. За это же время было освобождено из под стражи 37 человек, из них проходило по делам прокуратур - 17, по делам милиции - 20. Суды оправдали 4 обвиняемых, дела которых расследовались следователями прокуратур, и 3 - милицией. В стадии расследования были прекращены дела на одного, чьё дело вела прокуратура, и 8 - милиция. Мера пресечения была изменена одному обвиняемому следователем прокуратуры и 9 - милицией. В связи с применением меры наказания, не связанной с лишением свободы, вышли на волю 11 человек, чьи дела расследовались сотрудниками МВД. Из 16 оправданных и тех, чьи дела были прекращены в стадии расследования, 3 были арестованы по санкции прокурора УстьАбаканского района Алешина, 4 - прокурора Таштыпского района Алябьева, 3 - прокурора Боградского района Макаренко, 1 - прокурора Алтайского района Киселёва. Остальные арестовывались прокурорами Аскизского, Бейского и Боградского районов и Черногорска. Прокуроры Абакана, Саралинского и Ширинского районов не допустили ни одного случая необоснованного ареста. В 1954 г. за дачу незаконных санкций на арест понесли дисциплинарную ответственность прокуроры Асеева и Алешин. Поскольку наиболее неблагополучно обстояли дела в Таштыпском районе, где каждый шестой арестованный освобождался из-под стражи, Алябьев был снят с работы [6. Л. 38].

Статья 17 Положения о прокурорском надзоре в СССР от 24 мая 1955 г. требовала «строго следить за тем, чтобы ни один гражданин не подвергся незаконному и необоснованному привлечению к уголовной ответственности» [7. С. 143]. А в статье 18 содержалось положение о том, что «при решении вопроса о санкции на арест прокурор обязан тщательно ознакомиться со всеми материалами, обосновывающими необходимость ареста и в необходимых случаях лично допросить лицо, подлежащее аресту» [Там же]. Хакасские прокуроры не всегда следовали этим положениям.

В советской судебной системе предварительному следствию принадлежала решающая роль в определении вины или невиновности подозреваемого. Судебным инстанциям зачастую лишь приходилось фиксировать выводы следователей, поэтому любое оправдание обвиняемых становилось ударом по репутации прокурорских органов, по санкции которых невиновный длительное время содержался под стражей.

4 августа 1955 г. Генеральный прокурор СССР издал приказ, в котором признавалось, что незаконные 
задержания, аресты и необоснованные привлечения к уголовной ответственности до сих пор не изжиты и вызваны безответственным отношением прокуроров и работников следственных органов к исполнению служебных обязанностей. Р.А. Руденко отметил другой факт: прокуроры иногда необоснованно отказывали санкционировать аресты лиц, совершивших тяжкие преступления. И то и другое он расценивал как грубые нарушения закона, которые должны повлечь за собой строгую ответственность как прокуроров, так и следователей [3. С. 84]. Этот приказ требовал от прокурорских работников всячески лавировать, проявлять недюжинные аналитические способности и интуицию при выдаче санкций на арест.

В 1956 г. прокурорами Хакасии из-под стражи было освобождено 13 человек, арестованных их коллегами. Прокурор Алтайского района Жихарев подверг аресту 3, Ширинского района Балакирев и его помощник Чмыхалов и Таштыпского района Побежимов - по 1. Не допускали незаконных арестов прокуроры: Боградского района Грицун, Бейского - Асеева, Орджоникидзевского - Пивоваров, Усть-Абаканского - Алёшин. Областной прокурор предупредил Жихарева о том, что если он и дальше будет столь же безответственно относиться к своим обязанностям, то встанет вопрос о его дальнейшем пребывании в должности. Однако прокурор Алтайского района предупреждению не внял и в 1957 г. снова допустил незаконный арест. Взысканиям были подвергнуты все прокуроры, арестовывавшие освобожденных впоследствии граждан, С.П. Адушкин заверил обком в том, что «мы и впредь будем так поступать, ибо этого требует от нас партия и правительство» [9. Л. 16-17].

Некоторые прокуроры, такие как Асеева и Алешин, сделали должные выводы и начали работать лучше. Набравшись опыта, они стали серьезнее оценивать доказательства, представлявшиеся им следственными органами, и перестали подвергать подозреваемых аресту по первому требованию следователей. Другие главы местных прокуратур были не столь щепетильны, и на них приходилось оказывать давление вышестоящему прокурору.

В 1958 г. суды области оправдали 20 человек, из которых под стражей содержалось 5. Дела 12 оправданных расследовались милицией, 8 - следователями прокуратур. Особенно «отличился» прокурор Ширинского района Балакирев, судебные органы оправдали 9 арестованных им подсудимых [15. Л. 8]. Прокуроры не всегда соглашались с оправдательными приговорами и пытались опротестовать таковые в вышестоящих судебных инстанциях. В 1958 г. областной суд по протестам прокуроров отменил 6 оправдательных приговоров народных судов [9. Л. 16-17]. Протесты на оправдательные или слишком мягкие приговоры были, в числе прочего, попыткой прокуроров обосновать свое решение об аресте того или иного гражданина.

При этом суды не всегда шли на поводу у прокурорских органов. В 1954 г. прокуратуры ХАО принесли 31 протест на мягкость приговоров, из которых областной суд удовлетворил 24, или 77,3\% [6. Л. 55]. А за первые 8 месяцев 1960 г. прокуроры подали про- тесты на 21 приговор судов, значительная часть из которых была отклонена областным судом [15. Л. 11]. Судебные инстанции становились все более независимыми и выносили решения исходя из закона и собственных убеждений.

Заметную роль органы прокуратуры играли и в отправлении гражданского судопроизводства. В 1954 г. городские и районные прокуратуры Хакасии предъявили 587 гражданских исков, на 207 больше, чем в 1953 г. Большинство исков прокуратуры предъявляли в пользу колхозов по взысканию дебиторской задолженности и возмещения нанесенного ущерба. Всего за 1954 г. народные суды области рассмотрели 5768 гражданских дел, из них с участием прокуроров рассматривалось 1 588. Позднее эта цифра не подтвердилась. Целевые проверки и комплексные ревизии работы городских и районных прокуратур показали, что прокуроры в своих отчетах завышали показатели и на самом деле принимали участие в рассмотрении лишь 1382 дел. За предоставление заведомо ложных данных к дисциплинарной ответственности была привлечена прокурор Бейского района Асеева. При этом прокурор Черногорска участвовал в разборе 473 гражданских дел из 1213 рассмотренных в его городе в 1954 г. По мнению областного прокурора, его подчиненный выступал в суде, не учитывая важности и сложности дела, предъявляя иски на небольшие суммы и в интересах лиц, которые сами могли защищать свои права в суде. Областная прокуратура в 1954 г. принимала участие в рассмотрении 173 гражданских дел [6. Л. 69-72].

Советские прокуроры были лучше подготовлены в области уголовного права, и им порой было сложно заниматься гражданскими делами, что заставляло одних завышать цифры для отчетности, а других - принимать на себя обязательства по как можно большему числу несложных гражданских дел, чтобы повысить собственную значимость в данной сфере деятельности.

Недочеты в работе органов прокуратуры во многом объяснялись их проблемами с кадровым составом. В послевоенный период в Хакасии был отмечен рост горно-рудной промышленности, шло строительство железных дорог, в область прибывало большое количество ссыльных и спецпоселенцев. Все это приводило к росту населения, но численность правоохранительных органов оставалась прежней.

Ещё в октябре 1952 г. Хакасский обком по представлению областной прокуратуры сделал запрос на имя Генерального прокурора СССР Г.Н. Сафонова об увеличении штата прокуратур Абакана, Черногорска и Таштыпского района. Прокуратура СССР переадресовала эту просьбу в прокуратуру РСФСР, откуда пришел ответ, что для установления дополнительных должностей по штатам данных прокуратур необходимо было исключить такие же должности из штатов других прокуратур Красноярского края, с чем не были согласны ни республиканская прокуратура, ни прокуратура края [17. Л. 3]. Руководство краевой прокуратуры предпочитало держать своих хакасских коллег в «черном теле», уделяя внимание непосредственно подчиненным ему прокурорским органам. В результа- 
те на прокурорских работников Хакасии ложилась слишком большая нагрузка.

На 10 апреля 1953 г. в Хакасской областной прокуратуре работали следующие сотрудники: должность областного прокурора занимал В.Д. Абрамов. На посту Василий Дмитриевич находился с 15 июля 1948 г. На тот момент его судьба была предрешена. В день похорон И.В. Сталина 9 марта 1953 г. он решил помянуть вождя обильным распитием спиртных напитков, что не понравилось вышестоящему начальству, и В.Д. Абрамов был исключен из партии и снят с должности [18. С. 200]. Новым прокурором области был назначен Степан Петрович Адушкин, занимавший эту должность до ноября 1965 г. Заместителем областного прокурора с 1 апреля 1949 г. был И.М. Хатуцкий. Израиль Менделевич имел среднее юридическое образование и трудился в органах юстиции с августа 1933 г. Помощником областного прокурора по кадрам с 7 августа 1950 г. был А.В. Баранов. Юридического образования Андриан Варфоломеевич не имел, что компенсировалось опытом работы в органах юстиции, где он служил с сентября 1933 г. Помощником областного прокурора по уголовносудебному надзору с 25 июля 1946 г. была Р.М. Готлиб. Реля Моисеевна имела высшее юридическое образование, в органах юстиции работала с февраля 1943 г. В.К. Михайлова занимала должность помощника областного прокурора по спецделам с 5 сентября 1944 г. Общее образование Веры Михайловны ограничивалось девятью классами, а юридическое - курсами переподготовки. В органах юстиции она работала с 18 июня 1942 г. Помощником облпрокурора по следствию с 17 сентября 1952 г. был Н.3. Алешин. Николай Захарович имел незаконченное высшее юридическое образование, его работа в органах прокуратуры началась в июле 1949 г. Должность помощника главы областной прокуратуры по следствию с 10 мая 1951 г. занимал П.К. Каражаков. Пётр Кириллович имел среднее юридическое образование, в органах прокуратуры работал с 1946 г. Исполняющим обязанности помощника облпрокурора по надзору за милицией был назначен Г.Д. Анопченко. Георгий Дмитриевич трудился в прокурорских органах с 1938 г., у него было среднее юридическое образование. В марте 1953 г. исполняющим обязанности помощника прокурора области по гражданско-судебному надзору была назначена А.С. Юскова. Анна Семёновна имела среднее юридическое образование, в органах прокуратуры была новичком. Исполняющим обязанности старшего следователя облпрокуратуры с 25 октября 1952 г. был Г.П. Падеров. Георгий Петрович имел среднее юридическое образование, в органах прокуратуры работал с 1950 г. Всего в областной, городских и районных прокуратурах Хакасии к указанной дате работало 36 человек. Почти все были членами КПСС, кандидатами в члены партии или комсомольцами [19. Л. 171-172].

Сотрудники областной прокуратуры в основном были опытными и подготовленными юристами. Стаж их работы в органах прокуратуры и на занимаемых должностях позволял профессионально исполнять свои обязанности. Большинство имели, по крайней мере, среднее юридическое образование, все больше было специалистов с высшим и незаконченным высшим образованием. Но если качественный состав прокурорских работников был вполне удовлетворительным, то их количество не позволяло должным образом выполнять стоявшие перед ними задачи.

В исследуемый период население в Хакасии продолжало расти. Особенно это актуально было для Ширинского, Боградского, Таштыпского и Аскизского районов, где с 1954 г. началось освоение целинных и залежных земель. Там образовывались новые предприятия, совхозы и МТС. Росло и городское население. В 1954 г. прокуратура Ширинского района расследовала 200 дел, туда поступило 1376 жалоб; прокуратура Таштыпского района провела расследование 92 дел и получила 629 жалоб, Аскизского района - 92 и 467, Боградского - 125 дела и 570 жалоб. При таком объёме работ аппарат этих прокуратур состоял лишь из прокурора и следователя, кроме прокуратуры Ширинского района, где был еще помощник прокурора. В прокуратуре Абакана в составе которой до 15 декабря 1954 г. имелось 5 оперативных работников, было расследовано в 1954 г. 125 дел, получено и разрешено 666 жалоб. При возраставшем объеме работы, превышавшем возможности указанных прокурорских органов, прокуратура РСФСР по-прежнему не шла навстречу областным властям в их просьбах об увеличении штатов местных прокуратур. В этих условиях областная прокуратура была вынуждена пойти на радикальный шаг - прокуратуре СССР было сделано предложение о ликвидации городской прокуратуры Абакана. Высвободившийся аппарат С.П. Адушкин предлагал использовать так: двух оперативных и одного технического работника зачислить в аппарат областной прокуратуры, других двух оперативных и одного технического работника направить в сельские районы, должности уборщицы и шофера сократить. Функции упраздненного ведомства предполагалось возложить на соответствующие отделы областной прокуратуры [20. Л. 2].

Данное предложение являлось вынужденной мерой, после того как вышестоящие инстанции отказали областной прокуратуре в помощи. Однако это могло дать лишь временное облегчение. Троих сотрудников было явно недостаточно для того, чтобы укрепить районные прокуратуры, при этом возрастала нагрузка на областную.

В 1955 г. кроме упразднения прокуратуры Абакана С.П. Адушкин предлагал объединить прокуратуры Алтайского и Бейского районов, создав межобластную прокуратуру [Там же. Л. 4]. Областной прокурор при этом ссылался на Постановление ЦК КПСС и Совета министров СССР от 14 октября 1954 г. «О существенных недостатках в структуре министерств и ведомств СССР и мерах по улучшению работы государственного аппарата». В этом постановлении отмечалось, что «в министерствах и ведомствах грубо нарушены нормальные соотношения между начальствующим составом и исполнителями, в результате чего, как правило, на каждые 3-4 работника управленческого аппарата приходится один начальник» [8. С. 510]. Таким образом, объединение двух проку- 
рорских органов предполагалось не только для оптимизации расходов, а еще и в исполнение политики борьбы с бюрократизмом.

Дальнейшим шагом в реформировании прокурорских органов было изменение их структуры в соответствии с новой политикой руководства страны. 7 апреля 1956 г. Постановлением Президиума Верховного Совета СССР была утверждена новая структура центрального аппарата прокуратуры СССР. В аппарате образовывались 3 управления, 9 отделов, и приемная и канцелярия - на правах отделов [7. С. 148-149]. Приказом Генерального прокурора СССР от 10 апреля 1956 г. были упразднены отделы по надзору за органами милиции как в Прокуратуре СССР, так и в прокуратурах республик, краев и областей, а их функции передавались в следственные отделы. Переименовывался ряд отделов: отдел по специальным делам стал называться отделом по надзору за следствием в органах государственной безопасности; отдел уголовно-судебного надзора становился отделом по надзору за рассмотрением в судах уголовных дел; отдел гражданско-судебного надзора - отделом по надзору за рассмотрением в судах гражданских дел; отдел по надзору - за местами заключения; справочно-информационный отдел - отделом систематизации законодательства [Там же. С.149]. По мнению А.Г. Звягинцева, «новой структурой и переименованиями отделов руководство стремилось подчеркнуть те изменения, которые наметились в этой правоохранительной системе, как бы показывая, что с прошлым раз и навсегда покончено» [3. С. 85].

Новые названия отделов давали более четкие представления об объеме их полномочий. Довольно трудно было догадаться, чем, например, занимался отдел по специальным делам. Этим переименованием Генеральный прокурор стремился не только порвать с прошлым, но и показать открытость органов прокуратуры.

Реформа прокурорских органов СССР не помогла решению проблем прокуратур Хакасии. После упразднения в 1955 г. прокуратуры Абакана были увеличены штаты прокуратур Ширинского, Аскизского и Таштыпского районов. Однако с 1955 по 1959 г. в области в эксплуатацию были сданы Абазинский рудник, железная дорога Абакан - Сталинск (Новокузнецк), Усть-Абаканский гидролизный завод, было создано 14 новых совхозов, начато строительство новых предприятий. Штаты же прокурорских органов Хакасии оставались неизменными. Особенно большая нагрузка приходилась на «укрепленные» за счет ликвидации Абаканской прокуратуры ведомства - прокуратуры вышеперечисленных районов и областную прокуратуру. Так, в 1958 г. прокуратура Ширинского района закончила расследование 255 уголовных дел. Два следователя этого ведомства не справлялись с таким объёмом работы, и расследованием более 60 дел были вынуждены заниматься районный прокурор и его помощник. Четверо оперативных сотрудников прокуратуры Таштыпского района в 1958 г. закончили расследование 101 дела. Трое сотрудников Аскизской районной прокуратуры в 1958 г. занимались расследованием 151 уголовного дела. Чрезмерная нагрузка сотрудников прокурорских органов заставила прокурора области 20 февраля 1959 г. обратиться к Прокурору РСФСР А.А. Круглову с очередной просьбой об увеличении штатов и, в связи с территориальной разбросанностью подведомственных территорий, о выделении 2 легковых автомобилей для прокуратур Ширинского и Аскизского районов [21. Л. 4].

В исследуемое время органам юстиции и правопорядка приходилось работать по сталинским законам при изменившихся государственной политике и общественных настроениях. Законодательство начало меняться только к концу десятилетия, а до того работникам судебных и правоохранительных органов часто приходилось искать компромисс между требованиями законов и политической ситуацией.

В Хакасии прокурорские органы действовали в непростых условиях. ХАО как сибирский регион была местом отбывания наказания большого количества осужденных, многие из которых, освободившись, оставались в области на постоянное место жительства. Рост промышленности, транспорта и сельского хозяйства и последовавшее вследствие этого увеличение населения также сказались на криминальной ситуации в Хакасии. При этом численность прокурорских работников в области в середине 1950-х гг. уже не отвечала потребностям региона. Вышестоящие же прокуратуры были равнодушны к просьбам местных властей, и недостаток финансирования сказывался на периферийных прокуратурах, им самим приходилось искать решение проблем, что при скудных ресурсах было сложно. Нехватка прокурорских работников приводила к перегруженности имевшихся, это провоцировало волокиту при рассмотрении уголовных дел и заявлений граждан и дискредитировало саму прокурорскую работу.

\section{ЛИТЕРАТУРА}

1. История прокуратуры России. Историко-правовой анализ : учеб. пособие; под ред. А.Г. Звягинцева. М. : ЮНИТИ-ДАНА, 2010.223 с.

2. Звягинцев А.Г. Руденко. М. : Молодая гвардия, 2007. 482 с.

3. Звягинцев А.Г., Орлов Ю.Г. Заложники вождей. Советские и российские прокуроры. ХХ век. 1954-1992. М. : Рос. полит. энциклопедия (РОССПЭН), 2006. 648 c.

4. Кирячев М.В. История территориальных органов прокуратуры СССР в 1953-1964 гг. (на материалах Центрального Черноземья) : автореф. дис. ... канд. ист. наук. Курск, 2006. 20 с.

5. Доржу 3.Ю., Шмидт И.Д. Организация и функционирование органов прокуратуры Тувинской автономной области (1944-1961 гг.) // Вестник ТГПУ. 2016. № 5 (170). С. 151-158.

6. Национальный архив Республики Хакасия (далее НАРХ). Ф. Р-50. Оп. 2 с. Д. 122.

7. Советская прокуратура : сб. документов. М. : Юрид. лит., 1981. 288 с.

8. КПСС в резолюциях и решениях съездов, конференций и пленумов ЦК. 1898-1971. Т. 6: 1941-1954. 8-е изд., доп. и испр. М. : Политиздат, 1971. 527 c. 
9. НАРХ. Ф. Р-50. Оп. 2 с. Д. 123.

10. НАРХ. Ф. Р-50. Оп. 1. Д. 9.

11. НАРХ. Ф. 2 Оп. 1. Д. 2435.

12. НАРХ. Ф. Р-50. Оп. 2 с. Д. 124.

13. Лебина Н.Б. Повседневность эпохи космоса и кукурузы: Деструкция большого стиля: Ленинград, 1950-1960-е годы. СПб. : Крига; Победа, 2015. $484 \mathrm{c}$.

14. Внеочередной ХХІ Съезд Коммунистической Партии Советского Союза. 27 января - 5 февраля 1959 года. Стенографический отчет. М. : Гос. изд-во полит. лит., 1959. 592 с.

15. НАРХ. Ф. Р-50. Оп. 2 с. Д. 126.

16. Земсков В.Н. Ситуация с заключёнными в первые послесталинские годы // Известия Самарского научного центра Российской академии наук. 2014. Т. 16, № 3. С. 130-136.

17. НАРХ. Ф. 2. Оп. 1. Д. 2012. Л. 3

18. Гавриленко В.К. Казнь прокурора. Документальное повествование. Абакан : АОЗТ «Хакасинтерсервис», 2000.240 с.

19. НАРХ. Ф. 2. Оп. 1. Д. 2008.

20. НАРХ. Ф. 2. Оп. 1. Д. 2013.

21. НАРХ. Ф. 2. Оп. 1. Д. 2519.

Статья представлена научной редакцией «История» 27 ноября 2017 г.

\section{PUBLIC PROSECUTION BODIES OF THE KHAKASS AUTONOMOUS REGION DURING THE POST-STALIN PERIOD (1953-1960)}

Vestnik Tomskogo gosudarstvennogo universiteta - Tomsk State University Journal, 2018, 430, 110-119.

DOI: 10.17223/15617793/430/15

Vladimir A. Pecherskiy, Khakassia Research Institute Language, Literature, History (Abakan, Russian Federation). E-mail: volody75.75@mail.ru

Keywords: Khakass Autonomous Region; public prosecutor's authorities; post-Stalin period; law and order.

The aim of this article is the study of various aspects of the activities of the public prosecutor's bodies of the Khakass Autonomous Region during the period from I.V. Stalin's death (1953) to the last year of the operation of the 1926 RSFSR Criminal Code (1960). The source basis of the research is documents from the National Archive of the Republic of Khakassia first introduced for scientific use, and published scientific works. The restoration of "socialist legality" went along with the strengthening of the role of the prosecutor's office. The activities of the public prosecutor's bodies amplified during the studied period. In the framework of general supervisory work, the public prosecutor's bodies of the Khakass Autonomous Region carried out 754 inspections of execution of various laws in 1953, 867 inspections of this kind were carried out in 1954. Inspections resulted in 203 objections in 1953, 429 in 1954. 222 persons were brought to disciplinary responsibility in 1953, 377 in 1954. Protection of rights and legitimate interests of citizens was one of the most important functions of the public prosecutor's bodies. In 1954 the prosecutor's office of Khakassia received 7476 complaints, of them 1224 complaints were to city and regional prosecutor's offices, the others to the regional prosecutor's office. It was 365 complaints more than in 1953. People complained to the prosecutor's offices about sentence execution on cases of collecting alimony and of labour legal relationship. A special place in the activity of prosecutor's bodies was occupied with work on observance of the law in the part of arrests and the reasonableness of bringing to justice. The city and regional prosecutor's offices of Khakassia issued sanctions to arrest 839 people in 1954. For the same period, 37 people were discharged from custody. Some prosecutors were brought to disciplinary responsibility for unreasonable issuing of sanctions for arrest. During the studied period public prosecutor's bodies of Khakassia experienced difficulties with personnel: there were not enough people to fully execute the duties. Public prosecutor's workers were excessively busy. In 1954 the prosecutor's office of the Shira District investigated 200 cases and received 1376 complaints, of the Tashtyp District investigated 92 cases and received 629 complaints, the prosecutor's office of the Askiz District had 92 cases and 467 complaints, the prosecutor's office of the Bograd District had 125 cases and 570 complaints. With this load, the prosecutor's offices consisted only of the prosecutor and the investigator; the prosecutor's office of the Shira District also had an assistant prosecutor. The author comes to a conclusion that the heads of the prosecutor's offices of the RSFSR and Krasnoyarsk Krai did not pay due attention to the needs of the public prosecutor's bodies of Khakassia; as a consequence, it was difficult for the latter to cope with their duties.

\section{REFERENCES}

1. Zvyagintsev, A.G. (ed.) (2010) Istoriya prokuratury Rossii. Istoriko-pravovoy analiz [History of the Prosecutor's Office of Russia. Historical and legal analysis]. Moscow: YuNITI-DANA.

2. Zvyagintsev, A.G. (2007) Rudenko. Moscow: Molodaya gvardiya. (In Russian).

3. Zvyagintsev, A.G. \& Orlov, Yu.G. (2006) Zalozhniki vozhdey. Sovetskie i rossiyskie prokurory. XX vek. $1954-1992$ [Hostages of the leaders. Soviet and Russian prosecutors. 20th century. 1954-1992]. Moscow: ROSSPEN.

4. Kiryachev, M.V. (2006) Istoriya territorial'nykh organov prokuratury SSSR v 1953-1964 gg. (na materialakh Tsentral'nogo Chernozem'ya) [History of the territorial bodies of the Prosecutor's Office of the USSR in 1953-1964 (on the materials of the Central Chernozem Region)]. Abstract of History Cand. Diss. Kursk.

5. Dorzhu, Z.Yu. \& Shmidt, I.D. (2016) The organization and functioning of the prosecution of Tuva Autonomous Region (1944-1961 biennium). Vestnik TGPU - TSPU Bulletin. 5 (170). pp. 151-158. (In Russian).

6. National Archive of the Republic of Khakassia (NARKh). Fund R-50. List 2 pp. File 122. (In Russian).

7. Pavlishchev, K.S. \& Shishkov, S.A. (eds) (1981) Sovetskaya prokuratura: sb. dokumentov [The Soviet Prosecutor's Office: documents]. Moscow: Yuridicheskaya literatura.

8. Fedoseev, P.N. \& Chernenko, K.U. (eds) (1971) KPSS v rezolyutsiyakh i resheniyakh s"ezdov, konferentsiy i plenumov TsK. 1898-1971 [The CPSU in resolutions and decisions of congresses, conferences and plenums of the Central Committee. 1898-1971]. Vol. 6. Moscow: Politizdat.

9. National Archive of the Republic of Khakassia (NARKh). Fund R-50. List 2 pp. File 123. (In Russian).

10. National Archive of the Republic of Khakassia (NARKh). Fund R-50. List 1. File 9. (In Russian).

11. National Archive of the Republic of Khakassia (NARKh). Fund 2 List 1. File 2435. (In Russian).

12. National Archive of the Republic of Khakassia (NARKh). Fund R-50. List 2 s. File 124. (In Russian). 
13. Lebina, N.B. (2015) Povsednevnost' epokhi kosmosa i kukuruzy: Destruktsiya bol'shogo stilya: Leningrad, 1950-1960-e gody [Everyday life of the space and corn epoch: Destruction of a great style: Leningrad, 1950s-1960s]. St. Petersburg: Kriga; Pobeda.

14. USSR CP. (1959) Vneocherednoy XXI S"ezd Kommunisticheskoy Partii Sovetskogo Soyuza. 27 yanvarya - 5 fevralya 1959 goda. Stenograficheskiy otchet [Extraordinary XXI Congress of the Communist Party of the Soviet Union. January 27 - February 5, 1959. Verbatim report]. Moscow: Gosudarstvennoe izdatel'stvo politicheskoy literatury.

15. National Archive of the Republic of Khakassia (NARKh). Fund R-50. List 2 pp. File 126. (In Russian).

16. Zemskov, V.N. (2014) Condition of prisoners in the first post-Stalin years. Izvestiya Samarskogo nauchnogo tsentra Rossiyskoy akademii naukIzvestia of Samara Scientific Center of the Russian Academy of Sciences. 16:3. pp. 130-136. (In Russian)

17. National Archive of the Republic of Khakassia (NARKh). Fund 2. List 1. File 2012. Page 3. (In Russian).

18. Gavrilenko, V.K. (2000) Kazn' prokurora. Dokumental'noe povestvovanie [Execution of the prosecutor. A documentary narrative]. Abakan: AOZT "Khakasinterservis".

19. National Archive of the Republic of Khakassia (NARKh). Fund 2. List 1. File 2008. (In Russian),

20. National Archive of the Republic of Khakassia (NARKh). Fund 2. List 1. File 2013. (In Russian).

21. National Archive of the Republic of Khakassia (NARKh). Fund 2. List 1. File 2519. (In Russian).

Received: 27 November 2017 